\title{
Effects of the Essential Oil from Fruits of Schinus terebinthifolius Raddi (Anacardiaceae) on Reproductive Functions in Male Rats
}

\author{
Cristiano R. G. Affonso, ${ }^{a}$ Rozeverter M. Fernandes, ${ }^{a}$ Jamylla M. G. de Oliveira, ${ }^{a}$ \\ Maria do Carmo de Carvalho e Martins, ${ }^{b}$ Sidney G. de Lima, ${ }^{*, c}$ Gustavo R. de Sousa Júnior, ${ }^{c}$ \\ Maria Zenaide de Lima C. Moreno Fernandes*,d and Surama F. Zanini ${ }^{e}$ \\ ${ }^{a}$ Departamento de Morfofisiologia Veterinária, ${ }^{b}$ Departamento de Biofísica e Fisiologia, \\ ${ }^{c}$ Departamento de Química and ${ }^{d}$ Departamento de Bioquímica e Farmacologia, \\ Universidade Federal do Piauí, 64049-550 Teresina-PI, Brazil
}

${ }^{e}$ Centro de Ciências Agrárias, Universidade Federal do Espírito Santo, Alegres-ES, Brazil

\begin{abstract}
O óleo essencial de Schinus terebinthifolius foi analisado por CG e CG-EM. $\alpha$-Fencheno, limoneno, $\beta$-pineno, $\alpha$-felandreno e $\beta$-isosilvestreno representam aproximadamente $80 \%$ da composição do óleo. A toxicidade na reprodução de ratos Wistar machos foi avaliada. Não foram observadas mudanças na massa dos órgãos reprodutivos, no número e morfologia dos espermatozoides, nas taxas de reprodução e na massa corporal dos ratos machos após tratamento com o óleo essencial de S. terebinthifolius.
\end{abstract}

The essential oil of Schinus terebinthifolius (Anacardiaceae) was analyzed by GC and GC-MS. $\alpha$-Fenchene, limonene, $\beta$-pinene, $\alpha$-phellandrene, and $\beta$-isosylvestrene represent about $80 \%$ of the oil composition. The reproductive toxicity of the essential oil in Wistar male rats was evaluated. No changes were observed in the mass of the reproductive organs, number and morphology of spermatozoa, reproductive rates, and the body mass of offspring of male rats after treatment with the essential oil of S. terebinthifolius.

Keywords: Schinus terebinthifolius Raddi, GC-MS, essential oil, male reproductive toxicity, Wistar male rats

\section{Introduction}

Schinus terebinthifolius, also known as Brazilian pepper, aroeira-vermelha, Florida holly, pink pepper, or christmas-berry belongs to the Anacardiaceae family of plants. ${ }^{1}$ It is native to South and Central America and it can also be found in semitropical and tropical regions of the United States and Africa. ${ }^{2}$

S. terebinthifolius has been reported to have antifungal, ${ }^{3}$ healing ${ }^{4}$ and anti-allergic effects, ${ }^{5}$ among others. In Brazil, it is used in folk medicine for the treatment of inflammatory and hemostatic diseases ${ }^{6}$ as well venereal diseases, rheumatism, diarrhea, pain, gingivitis and fever. ${ }^{7,8}$ The extract of stem bark is widely used as an anti-inflammatory, to heal over or cicatrize wounds, whereas fruits are used for colds, fungal and bacterial infections. ${ }^{9}$

\footnotetext{
*e-mail: sidney@ufpi.edu.br, zmoreno@ufpi.br
}

The berries of $S$. terebinthifolius are rich in essential oil, which imparts a peppery flavor, and are used as a food seasoning that is highly sought after and of significant economic value. These fruits are also used in syrups, vinegar, and beverages in Peru as well as in Chilean wines. In some countries, dried and ground berries are used as a pepper substitute or as an adulterant of black pepper (Piper nigrum). They have also been used in the perfume industry. ${ }^{10}$ The leaves and reddish fruits are also rich in essential oil, and earlier investigations have reported high concentrations of monoterpenes along with some sesquiterpene hydrocarbons. Despite the positive findings of the pharmacological properties of $S$. terebinthifolius and its growing use in cooking, little research has been carried out to ensure the safety of using this species. Since this plant is widely used for medicinal purposes, and mutagenic (cytotoxic) activity has been detected in stem bark extracts, ${ }^{11}$ as well as hypersensitivity to the volatile oil, we decided to carry the analysis of the essential oil 
and evaluate its toxicity on the reproductive functions in Wistar male rats.

\section{Results and Discussion}

Analysis of the essential oil

Chromatographic analysis by GC-MS permitted the identification and quantification of $100 \%$ of the integrated components from the essential oil isolated from the fruits of $S$. terebinthifolius. Spectra were considered coincident if the similarity index was higher than $95 \%$. Twenty two components, including mono-, and sesquiterpenes were identified, with a yield of about $2.6 \%(\mathrm{w} / \mathrm{w})$ of dry fruit weight. The chemical composition of the essential oil is presented in Table 1.

When compared to literature data, our study evidenced some differences in the chromatographic profile as well as in quantitative composition. ${ }^{12-17}$ The major constituents were $\alpha$-fenchene (20.75\%), $\beta$-pinene (10.11\%), $\beta$-myrcene

Table 1. Chemical composition of the essential oil obtained by hydrodistillation from fruits of S. terebinthifolius

\begin{tabular}{lcc}
\hline Compounds & $\mathrm{IK}_{\text {Exp }}{ }^{\mathrm{a}}$ & Area / \% \\
\hline$\alpha$-Thujene & 954 & 0.71 \\
$\alpha$-Fenchene & 961 & 20.75 \\
Camphene & 962 & 0.24 \\
$\beta$-Pinene & 987 & 10.11 \\
$\beta$-Myrcene & 991 & 9.30 \\
Mentha-1(7),8-diene $<$ meta> & 999 & 2.32 \\
$\alpha$-Phellandrene & 1012 & 14.94 \\
Sylvestrene $<$ iso $>$ & 1018 & 13.87 \\
$\alpha$-Terpinene & 1022 & 0.86 \\
$p$-Cymene & 1030 & 1.16 \\
Limonene & 1038 & 20.81 \\
$\gamma$-Terpinene & 1062 & 1.03 \\
Terpinolene & 1087 & 0.84 \\
Terpineol-4 & 1174 & 0.46 \\
$\delta$-Elemene & 1332 & 0.12 \\
Unidentified & 1386 & 0.21 \\
$E$-Caryophyllene & 1408 & 0.78 \\
$\alpha$-Humullene & 1450 & 0.12 \\
Germacrene-D & 1471 & 0.83 \\
$\gamma$-Cadinene & 1503 & 0.07 \\
$\delta$-Cadinene & 1515 & 0.34 \\
Elemol & 1542 & 0.11 \\
& & Total: $100 \%$ \\
\hline
\end{tabular}

Retention indices relative to $\mathrm{C}_{8}-\mathrm{C}_{20} n$-alkanes.
(9.30\%), $\alpha$-phellandrene (14.94\%), limonene (20.81\%) and isosylvestrene (13.87\%). $\alpha$-Fenchene and isosylvestrene were found only in our study (Table 1). $\alpha$-Phellandrene and $\beta$-pinene were found at $14.94 \%$ and $10.11 \%$ in our study, while they represented an average of $7.0 \%$ and $1.5 \%$, respectively, in the study by Barbosa et al. ${ }^{12}$ Most of the oil samples from leaves, flowers and/or fruits of $S$. terebinthifolius collected at different locations revealed $\alpha$-pinene (15.01-51.82\%) as the major component, especially in those originating from India. ${ }^{13,16,17}$ Sabinene was found at $40.66 \%$ in the study of Gundidza et al. ${ }^{14}$ while it accounted for $3.49 \%$ in the study of Barbosa et al. ${ }^{12}$ Other major components detected by Barbosa et al..$^{12}$ in the oil from unripe fruits of $S$. terebinthifolius were $\alpha$-cadinol (20.60\%), $\delta$-cadinene (15.48\%), $\beta$-pinene $(10.21 \%)$ and epi- $\alpha$-muurolol $(9.89 \%)$. More recently Richter et al. ${ }^{18}$ indicated that $\alpha$-pinene $(16.9 \%), \alpha$-phellandrene $(21.1 \%)$, $\beta$-phellandrene (10.8\%) and limonene $(23.7 \%)$ were the major constituents of fruits of S. terebinthifolius.

\section{Acute oral toxicity study}

The toxicity study of the essential oil from S. terebinthifolius fruits showed that the oral dose of $5 \mathrm{~g} \mathrm{~kg}^{-1}$ did not produce any signs of acute toxicity or death in mice during 14 days of observation. So possibly the LD50 would be greater than $5 \mathrm{~g} \mathrm{~kg}^{-1}$. According to Kennedy et al. ${ }^{19}$ substances with LD50 greater than $5 \mathrm{~g} \mathrm{~kg}^{-1}$ can be considered nontoxic. These findings are in accordance with those described by Lima et al. ${ }^{20}$ using the extract from the bark of S. terebinthifolius.

\section{Reproductive toxicity study}

Reproductive toxicity can be defined as the occurrence of adverse effects on the reproductive system, which can result from exposure to environmental agents, drugs and diseases in general. In this study we evaluated the effects of treatment with the essential oil of $S$. terebinthifolius fruits in reproductive performance and body mass of offspring. There was no statistically significant difference regarding the offspring/mother ratio and reproductive rates analyzed when the groups treated with essential oil were compared with the control group. Additionally there were no significant changes in litter mass and body mass on Day 1 and Day 21 of life of offspring from rats treated with essential oil when compared to the control group (Table 2).

Fertility studies evaluate the outcome of mating after pre-treatment in at least one of the sexes. Evaluation of fertility and subsequent pregnancy provides important information about the functional consequences of the 
Table 2. Effects of the essential oil from fruits of S. terebinthifolius on reproductive performance and body mass of offspring

\begin{tabular}{|c|c|c|c|c|}
\hline \multirow{2}{*}{ Variables } & \multirow{2}{*}{ Control } & \multicolumn{3}{|c|}{ Essential oil/( $\left.\mathrm{mg} \mathrm{kg}^{-1}\right)$} \\
\hline & & 375 & 750 & 1500 \\
\hline Offsprin /mother ratio & $11.1 \pm 0.7$ & $10.2 \pm 1.0$ & $10.6 \pm 1.0$ & $9.7 \pm 0.4$ \\
\hline Fertility rate/\% & 44.4 & 61.1 & 58.3 & 57.1 \\
\hline Birth rate/\% & 94.68 & 99.1 & 93.67 & 95.12 \\
\hline Viability rate/\% & 100.00 & 99.1 & 98.65 & 97.43 \\
\hline Lactation rate $/ \%$ & 98.88 & 97.32 & 97.30 & 97.44 \\
\hline Litter mass at 1 day of life/g & $67.96 \pm 4.82$ & $62.90 \pm 5.33$ & $61.84 \pm 5.96$ & $58.48 \pm 1.54$ \\
\hline Litter mass at 21 days of life/g & $358.1 \pm 19.70$ & $363.5 \pm 27.09$ & $334.5 \pm 25.85$ & $326.5 \pm 18.82$ \\
\hline Offspring body mass at 1 day of life/g & $6.199 \pm 0.211$ & $6.245 \pm 0.294$ & $5.857 \pm 0.242$ & $6.049 \pm 0.225$ \\
\hline Offspring body mass at 21 days of life/g & $34.95 \pm 1.29$ & $39.43 \pm 2.70$ & $36.31 \pm 2.44$ & $37.85 \pm 2.55$ \\
\hline
\end{tabular}

Mass data are presented as mean \pm S.E.M.; number of females mated $=12-18$ animals per group.

chemical agent on the reproductive system. ${ }^{21}$ The results obtained demonstrated that treatment with the essential oil before mating did not affect the fertility of rats. Moreover, the measures of masses of reproductive organs like as the testes, epididymis and prostate, are useful for assessing male reproductive toxicity. ${ }^{21}$ A reduction in testes and epididymis mass indicates reduced fertility or contraceptive activity because these organs are responsible for the formation and maturation of sperm. ${ }^{22,23}$ The prostate is an accessory organ that secretes prostatic fluid, which is important to increase the motility and fertility of spermatozoa and its weight is androgen-dependent and may reflect changes in the endocrine and testicular function in animals..$^{21,24}$

In this study, body mass at the end of treatment and the relative gain of body mass in the groups treated with essential oil did not change significantly when compared to controls except for the body mass at the end of the treatment in group T2 $(\mathrm{p}<0.05)$. The relative mass $(\mathrm{g}$ per $100 \mathrm{~g})$ of the testes, epididymis and prostate of the groups treated with the essential oil did not differ significantly from the control group (Table 3). Our results showed that treatment of rats with the essential oil from fruits of S. terebinthifolius at three different doses by oral gavage for 60 days did not significantly alter the mass of reproductive organs, which indicates the absence of contraceptive activity.

Toxic substances can lead to male contraception by decreasing sperm density and/or by changing the morphology and function of sperm. ${ }^{25}$ The number and morphology of spermatozoa evaluation showed that treatment of rats with essential oil for 60 days at the three different doses by oral gavage did not significantly alter the number of spermatozoa in the epididymis tail or the percentage of spermatozoa with abnormal morphology when compared with the control group (Table 3). These data suggest the absence of adverse effects on the process of spermatogenesis. The values of reproductive variables analyzed in this study did not differ from the control group which confirms the absence of reproductive toxicity in male

Table 3. Effects of the essential oil from fruits of S. terebinthifolius on body weight and reproductive parameters of male rats

\begin{tabular}{|c|c|c|c|c|}
\hline \multirow{2}{*}{ Variables } & \multirow{2}{*}{ Control } & \multicolumn{3}{|c|}{ Essential oil $/\left(\mathrm{mg} \mathrm{kg}^{-1}\right)$} \\
\hline & & 375 & 750 & 1500 \\
\hline Body mass day $0 / \mathrm{g}$ & $141.6 \pm 7.74$ & $140.6 \pm 6.41$ & $139.7 \pm 5.88$ & $137.1 \pm 8.36$ \\
\hline Body mass day $60 / \mathrm{g}$ & $313.8 \pm 13.58$ & $272.3 \pm 14.49$ & $261.7 \pm 10.82^{*}$ & $284.8 \pm 8.725$ \\
\hline Body mass relative gain $/ \%$ & $124.5 \pm 9.71$ & $104.9 \pm 8.16$ & $96.24 \pm 12.14$ & $94.47 \pm 12.05$ \\
\hline Sperm number $\left(\times 10^{6}\right)$ & $144.2 \pm 12.8$ & $155.1 \pm 8.5$ & $135.5 \pm 17.9$ & $148.0 \pm 23.84$ \\
\hline Abnormal sperm/\% & $1.70 \pm 0.35$ & $1.88 \pm 0.50$ & $2.05 \pm 0.60$ & $1.93 \pm 0.55$ \\
\hline \multicolumn{5}{|l|}{ Relative mass/(g per $100 \mathrm{~g})$} \\
\hline Testis & $0.775 \pm 0.026$ & $0.790 \pm 0.050$ & $0.776 \pm 0.080$ & $0.795 \pm 0.031$ \\
\hline Epididymis & $0.359 \pm 0.016$ & $0.387 \pm 0.024$ & $0.382 \pm 0.030$ & $0.353 \pm 0.013$ \\
\hline Prostate & $0.199 \pm 0.015$ & $0.192 \pm 0.008$ & $0.186 \pm 0.012$ & $0.181 \pm 0.009$ \\
\hline
\end{tabular}

Data are presented as mean \pm S.E.M. $(n=6-9$ animals per group $)$. 
rats. However, this investigation should be pursued with plant material from different geographical areas, in order to relate variations in chemical composition of essential oils and extracts with the biological activity.

\section{Experimental}

Plant material

The botanical material was collected at Cia. Vale do Rio Doce (CVRD) Reserva Florestal Rio Doce S/A (Brazil) and the vegetable material and voucher specimen were deposited at herbarium of the Florestal Reserve of CVRD under the number 439144, collector No. 5734.

Volatile constituent

The ripe fruits of S. terebinthifolius were ground and subjected to hydrodistillation for $1.5 \mathrm{~h}$ using in a Clevengertype apparatus. The oil was collected and dried using anhydrous sodium sulfate and, after filtration, stored under low light conditions at $<10{ }^{\circ} \mathrm{C}$ until analysis.

\section{Essential oil analysis by GC and GC-MS}

The gas chromatography-mass spectra (GC-MS) analyses were performed using a Shimadzu GC-17A/MS QP5050A-GC-MS system (EI mode $70 \mathrm{eV}$, source temperature $260{ }^{\circ} \mathrm{C}$, scanned mass ranged 43-350 amu). The operating conditions were: DB-5HT column (J \& W Scientific, $30 \mathrm{~m} \times 0.25 \mathrm{~mm}$ i.d. $\times 0.1 \mu \mathrm{m}$ film thickness); helium as carrier gas at a flow rate of $1.0 \mathrm{~mL} \mathrm{~min}^{-1}$ with split ratio of $1: 30$; temperature program from $60{ }^{\circ} \mathrm{C}(2 \mathrm{~min})$ to $180{ }^{\circ} \mathrm{C}$ at $2^{\circ} \mathrm{C} \mathrm{min}^{-1}$ and then from $180^{\circ} \mathrm{C}$ (4 min) to $260^{\circ} \mathrm{C}$ at $10^{\circ} \mathrm{C} \mathrm{min}^{-1}$, with a final hold of $10 \mathrm{~min}$ at $260^{\circ} \mathrm{C}$. The identification of the essential oil (EO) components was accomplished by matching their mass spectra with those recorded in the Wiley $275 \mathrm{~L}$ database.

The identity of each compound was confirmed by comparison of its retention index relative to $\mathrm{C}_{8}-\mathrm{C}_{20}$ n-alkanes (Fluka Analytical, $1.0 \mathrm{~mL}$ alkane standard solution). The retention indices were compared to those of the literature. ${ }^{6,26,27}$ Samples of $1 \mu \mathrm{L}$ of oil diluted in $5 \%$ dichloromethane were injected. These analyses were carried out by gas chromatography with flame ionization detection (GC-FID) using an Agilent 5975C instrument equipped with a capillary column coated with DB-5 (30 m $\times 0.25 \mathrm{~mm}$ i.d. $\times 0.25 \mu \mathrm{m}$ film thickness; J \& W Scientific, Folsom, CA, USA). GC oven temperature and conditions were as described above to GC-MS. The detector and injector temperatures were held at $260^{\circ} \mathrm{C}$ and hydrogen used as carrier gas at a flow rate of $1.0 \mathrm{~mL} \mathrm{~min}^{-1}$, and split mode (1:10). The GC-FID was also used for relative quantification using area percent.

\section{Animals}

Wistar male rats were obtained from the Animal Facility for Maintenance of Animals for Experimentation of the Federal University of Piauí (UFPI). All animals were previously adapted to laboratory conditions for 14 days before the start of the experiment. The animals were maintained under standard conditions of temperature room ( $23 \pm 1^{\circ} \mathrm{C}$ ) and light cycle (12 h light/12 h dark). They were provided with a rodent-pellet diet and water $\mathrm{ad}$ libitum. All experimental procedures were approved by UFPI's Ethics Committee on Animal Experiments, protocol number 007/09.

\section{Doses and treatments}

The animals were treated with essential oil and vehicle Tween 80 at a ratio of $1: 1$ in order to facilitate the administration and to reduce possible irritation (pure essential oil). Wistar male rats (120-150 g) were randomly divided into four groups $(\mathrm{n}=10)$. A control group (Tween $801.5 \mathrm{~g} \mathrm{~kg}^{-1}$ ) and three groups were treated with different doses $\left(0.375 \mathrm{~g} \mathrm{~kg}^{-1}, 0.75 \mathrm{~g} \mathrm{~kg}^{-1}\right.$, and $\left.1.5 \mathrm{~g} \mathrm{~kg}^{-1}\right)$ of essential oil from $S$. terebinthifolius fruits. All animals were treated daily for 60 days by oral gavage.

\section{Acute oral toxicity study}

This assay was performed according to Brito in Swiss mice weighing $25 \pm 5.0 \mathrm{~g}$, randomly divided in 2 groups of 10 (5 males and 5 females) and housed individually. ${ }^{28}$ The animals were fasted overnight (12 h) with free access to water prior to the oral administration of distilled water (10 $\mathrm{mL} \mathrm{kg}^{-1}$ for the control group) or single doses of essential oil (dosage of $5 \mathrm{~g} \mathrm{~kg}^{-1}$ ), and observed continuously for $6 \mathrm{~h}$, intermittently for $24 \mathrm{~h}$ and then once a day for the next 14 days for general behavioral changes, signs of toxicity and mortality.

\section{Reproductive performance and body mass of offspring}

After treatment the male rats were placed together with females at a ratio of 1:2 for a period of seven days. Females have been previously examined to make sure they were fertile, the presence of sperm in the vaginal smear indicating successful mating. The female rats were then kept in individual cages, and after the birth of offspring 
reproductive variables were determined: relationship of offspring/mother fertility rate (number of pregnant rats/number of mated females); birth rate (number of offspring born alive/total number of offspring born); viability rate (number of offspring alive on day 4 postnatal/number of offspring born alive); lactation rate (number of offspring alive at day 21 postnatal/number of offspring born); and offspring body mass and litter mass at 1 and 21 days of life. ${ }^{29}$

Body mass and mass of the reproductive organs

The body mass was recorded weekly during the treatment period. After the mating period the male rats were euthanized by receiving a lethal dose of sodium thiopental $\left(100 \mathrm{mg} \mathrm{kg}^{-1}\right)$ and the testes, epididymis and prostate were removed and weighed. The mass of organs was expressed in terms of mass per one hundred grams of body mass (g per $100 \mathrm{~g}$ ).

\section{Number and morphology of spermatozoa}

To quantify the number of spermatozoa the epididymis tails were fragmented into small pieces and homogenized for $1 \mathrm{~min}$ in $10 \mathrm{~mL}$ of $0.9 \% \mathrm{NaCl}$ containing $0.5 \%$ Triton $\mathrm{X}-100$. The spermatozoa count took place in a hemocytometer chamber and the value was the mean of four fields multiplied by the correction factor $(3 \times 0.520833){ }^{30}$ To evaluate sperm morphology the ducts deferens from each animal was sectioned in $5 \mathrm{~mL}$ of $0.9 \% \mathrm{NaCl}$ and a sperm suspension was obtained. Smears prepared from each suspension were stained with $2 \%$ eosin and the samples were observed microscopically $(400 x)$ to evaluate the morphology of 200 spermatozoa per animal and to count the spermatozoa with abnormal heads and/or abnormal tails. ${ }^{31}$

\section{Statistics}

Values are expressed as mean \pm standard error of mean (SEM). Differences between groups were determined by analysis of (ANOVA) followed by the Tukey test. The rates of fertility, birth viability and lactation were analyzed using the chi-square test. The level of statistical significance was $5 \%(\mathrm{p}<0.05)$.

\section{Acknowledgments}

We are grateful to PIBIC-UFPI for its financial support and research fellowships and to Lapetro - UFPI for the chromatographic analysis; Dr. Carol Collins for revising this manuscript, Prof. Dr. Pedro J. M. Abreu and an anonymous reviewer for thoughtful suggestions and corrections; and Agrorosa Ltda (export company of pink pepper) for botanical material.

\section{References}

1. Lorenzi, H.; Árvores Brasileiras - Manual de Identificação e Cultivo de Plantas Arbóreas Nativas do Brasil, $1^{\text {st }}$ ed.; Plantarum: Nova Odessa, SP, Brasil, 1992.

2. Ferriter, A.; Brazilian Peppertree Management Plan for Florida. Florida Exotic Pest Plant Council, Brazilian Peppertree, Task Force: Florida, 1997.

3. Siddiqui, R.; Ahmad, H.; Sultan, S.; Ehteshamuddin, A. F. M.; Shirrem, S.; Pak. J. Sci. Ind. Res. 1996, 39, 43.

4. Melo Jr., E. J. M.; Raposo, M. J.; Neto, J. A.; Diniz, M. F. A.; Marcelino, C. A. C.; Sant'ana, A. E. G.; Phytomedicine 2002, 9, 109.

5. Machado, S. C.; Rosas, E. C.; Brito, F. A.; Heringe, A. P.; Oliveira, R. R.; Kaplan, M. A. C.; Figueiredo, M. R.; Henriques, M. G. M. O.; Int. Immunopharmacol. 2008, 8, 1552.

6. De Lima, S. G.; Moita Neto, J. M.; Costa, J. G. M. D.; Citó, A. M. G. L.; Reis, F. A. M.; J. Chil. Chem. Soc. 2009, 53, 1718.

7. Balbach, A.; A Flora Nacional na Medicina Doméstica, 1a. ed.; M.V.P.: São Paulo, Brasil, 1984.

8. Stasi Di, L. C.; Oliveira, G. P.; Carvalhaes, M. A.; Queiroz Junior, M.; Tien, O. S.; Kakinami, S. H.; Reis, M. S.; Fitoterapia 2002, 73, 69.

9. Matos, F. J. A.; O Formulário Fitoterápico do Professor Dias da Rocha, 9a. ed.; UFC: Fortaleza, CE, Brasil, 1997.

10. Khaled, F.; El-Massry; El-Ghorab, A. H.; Shaaban, H. A.; Shibamoto, T.; J. Agric. Food Chem. 2009, 57, 5265.

11. Carvalho, M. C. R. D.; Barca, F. N. T. V.; Agnez-Lima, L. F.; Medeiros, S. R. B.; Environ. Mol. Mutagen. 2003, 42, 185.

12. Barbosa, L. C. A.; Demuner, A. J.; Clemente, A. D.; De Paula, V. F.; Ismail, F. M. D.; Quim. Nova 2007, 30, 1959.

13. Chowdhury, A. R.; Tripathi, S.; Ind. Perfum 2001, 45, 257.

14. Gundidza, M.; Gweru, N.; Magwa, M. L.; Mmbengwa, V.; Samie, A.; Afr. J. Biotechnol. 2009, 8, 7164.

15. Ibrahim, M.; Fobbe, R.; Nolte, J.; Bull. Fac. Pharm. 2004, 42, 289.

16. Jamal, Y.; Agusta, A.; Majalah Farmasi Indonesia 2001, 12, 135.

17. Singh, A. K.; Singh, J.; Gupta, K. C.; Brophy, J. J.; J. Essent. Oil Res. 1998, 10, 697.

18. Richter, R.; Von Reuß, S. H.; König, W. A.; Phytochemistry 2010, 71, 1371.

19. Kennedy, G. L.; Ferenz, R. L.; Burgees, B. A.; J. Appl. Toxicol. 1986, 6, 145.

20. Lima, L. B.; Vasconcelos, C. F. B.; Maranhão, H. M. L.; Leite, V. R.; Ferreira, P. A.; Andrade, B. A.; Araújo, E. L.; Xavier, H. S.; Lafayette, S. S. L.; Wanderley, A. G.; J. Ethnopharmacol. 2009, 126, 468. 
21. U.S. Environmental Protection Agency; Guidelines for Reproductive Toxicity Risk Assessment, $1^{\text {st }}$ ed.; Washington, DC, 1996.

22. Gupta, R. S.; Yadav, V. P.; Dixit, V. P.; Dobhal, M. P.; Fitoterapia 2001, 72, 236.

23. Moundipa, F. P.; Kamtchouing, P.; Koueta, N.; Tantchou, J.; Foyang, N. P. R.; Mbiapo, F. T.; J. Ethnopharmacol. 1999, 65, 133.

24. Ahlgren, G.; Rannevik, G.; Lilja, H.; J. Androl. 1995, 16, 491.

25. Sá, R. C. S.; Leite, M. N.; Reporedo, M. M.; Almeida, R. N.; Contraception 2003, 67, 327.

26. Adams, M.; Berset, C.; Kessler, M.; Hamburger, M.; J. Ethnopharmacol. 2009, 121, 343.

27. Alencar, J. W.; Craveiro, A. A.; Matos, F. J. A.; Machado, M. I. L.; Quim. Nova 1990, 13, 282.
28. Brito, A. S.; Manual de Ensaios Toxicológicos in vivo; Ed. Unicamp: Campinas, 1994.

29. Elbetieha, A.; Al-Hamood, M. H.; Alkofahi, A.; Bataineh, H.; J. Ethnopharmacol. 1998, 61, 67.

30. Robb, G. W.; Amann, R. P.; Killian, G. J.; J. Reprod. Fertil. 1978, 54, 103.

31. Seed, J.; Chapin, R. E.; Clegg, E. D.; Dostal, L. A.; Foote, R. H.; Hurtt, M. E.; Klinefelter, G. R.; Makris, S. L.; Perreault, S. D.; Schrader, S.; Seyler, D.; Sprando, R.; Treinen, K. A.; Veeramachaneni, D. N.; Wise, L. D.; Reprod. Toxicol. 1996, 10, 237.

Submitted: May 2, 2011

Published online: November 1, 2011 